\title{
Gender differences in the immune system activities of sea urchin Paracentrotus lividus
}

\author{
Vincenzo Arizza a , Mirella Vazzana ${ }^{\mathrm{a}, *}$, Domenico Schillaci ${ }^{\mathrm{a}, \mathrm{b}}$, Debora Russo a , \\ Francesca Tiziana Giaramita ${ }^{a}$, Nicolò Parrinello ${ }^{\mathrm{a}}$ \\ a Dipartimento di Biologia ambientale e Biodiversità, Università degli Studi di Palermo, Via Archirafi, 18-90123 Palermo, Italy \\ b Dipartimento STEMBIO, Università degli Studi di Palermo, Via Archirafi, 32-90123 Palermo, Italy
}

\section{A R T I C L E I N F O}

\section{Article history:}

Received 28 August 2012

Received in revised form 28 November 2012

Accepted 30 November 2012

Available online 7 December 2012

\section{Keywords:}

Coelomocyte innate immunity

Ecological immunity

Gender

Cytotoxicity

Phagocytosis

Neutral red uptake.

\begin{abstract}
A B S T R A C T
In the immune system of vertebrates, gender-specific differences in individual immune competence are well known. In general, females possess more powerful immune response than males. In invertebrates, the situation is much less clear. For this purpose we have chosen to study the immune response of the two sexes of the echinoderm Paracentrotus lividus in pre- and post-spawning phases. The coelomic fluid from the echinoderms contains several coelomocyte types and molecules involved in innate immune defenses. In this article we report that the degree of immune responses in the P. lividus differs according to sex in both pre- and post-spawning phases. We found in all tests that females were more active than males. The results indicate that females possess a significant higher number of immunocytes consisting of phagocytes and uncolored spherulocytes. Since the immunological activity is mainly based on immunocytes, it was not surprising that females possessed the highest values of cytotoxicity and hemolysis activity and showed a greater ability to uptake neutral red and phagocyte yeasts cells, while the average number of ingested particles per active phagocyte was not significantly different. Furthermore, agglutinating activity was more evident in the coelomocyte lysate and coelomic fluid of females than in those of males. Finally we found that the acidic extract of female gonads possessed greater antimicrobial activity than that of male gonads. These results make it very likely that gender differences in the immune response are not restricted to vertebrates; rather, they are a general evolutionary phenomenon.
\end{abstract}

(c) 2012 Elsevier Inc. All rights reserved.

\section{Introduction}

Among vertebrates, males are more susceptible to parasitism and disease than females (Zuk, 1990; Zuk and McKean, 1996) and there is good evidence now that both humoral and cell-mediated immune responses are more efficient in female vertebrates than in male vertebrates (Grossman, 1989). For example, circulating levels of immunoglobulins in females far exceed those found in males (Butterworth et al., 1967), antigenic challenges stimulate stronger and more sustained immune responses in females (Terres et al., 1968) and males have relatively smaller immune defense organs (Moller et al., 1998). These differences are usually attributed to the immunosuppressive effect of testosterone (Zuk, 1990; Zuk and McKean, 1996).

Little is known about sex difference in immune responses of invertebrates and the rare studies are limited to arthropods such as scorpionflies, crickets, shrimps, dragonflies, and damselflies (Gray, 1998; Radhika et al., 1998; Kurtz et al., 2000; Kurtz and Sauer, 2001; Rolff, 2001; Yourth et al., 2002; Adamo, 2004; Fedorka et al., 2004) and mollusks (Matozzo and Marin, 2010).

\footnotetext{
Corresponding author at: Dipartimento di Biologia ambientale e Biodiversità, Via Archirafi, 18-90123 Palermo, Italy. Tel.: + 3991 23891804; fax: + 399123891847. E-mail address: mirella.vazzana@unipa.it (M. Vazzana).
}

Although the literature is rich with studies of the immune response in echinoderms, no relationship between the immune system and gender has ever been reported.

The innate immunity of echinoderms is usually divided into two broad categories: cellular and humoral immunity. Coelomocytes mediate the cellular responses to immune challenges through phagocytosis, encapsulation (Chia and Xing, 1996), cytoxicity (Arizza et al., 2007), and the production of antimicrobial agents (Schillaci et al., 2010). In addition, a variety of humoral factors found in the coelomic fluid, including lectins, agglutinins, and lysins (Canicatti, 1991) are important in host defense against pathogens and other foreign substances (Coffaro and Hinegardner, 1977; Smith et al., 1996; Gross et al., 1999; Pancer et al., 1999; Gross et al., 2000; Pancer, 2000; Kudriavtsev and Polevshchikov, 2004). A "defensome" involving a network of transcription factors and defense proteins, which elimante pathogens and potentially toxic chemicals, has been called into question (Hibino et al., 2006; Sodergren et al., 2006; Smith et al., 2010).

Cellular and humoral immune-reactions are launched immediately and are responsible for the clearance of bacteria and foreign particles (Yui and Bayne, 1983). Although maintaining immune competence is vitally important for the organism, it is also a very costly physiological function (Schmid-Hempel, 2003). The costs and benefits of immunity could differ greatly between males and females due to their differential reproductive strategies (Zuk, 1990; Zuk and McKean, 1996; Yourth et 
al., 2002; Zuk et al., 2004). In this respect, it has been suggested (Bateman, 1948; Andersson, 1994; Moore and Wilson, 2002) that females invest more in immunity because their fitness tends to be limited by longevity and the number of offspring they can rear, whereas males are more often limited by the number of mates they can inseminate (Bateman's principle).

Paracentrotus lividus is a very common species of both ecological and local economic importance. Phagocytes and uncolored spherulocytes have an important function in the immune system. In particular, we observed that phagocytes are able to ingest Saccharomyces cerevisiae yeasts, while uncolored coelomocytes are capable, in association with amoebocytes, of killing the rabbit blood cells and K562 tumor cells by destroying their membranes (Arizza et al., 2007). For this reason, the number of these coelomocytes and their cellular activity levels represent a good immune surveillance indicator.

So to determine whether the sea urchin shows gender differences similar to vertebrates we, for the first time, evaluated the difference in vitro of the same immunity-linked parameters in both genders in pre-spawning (PrS) and post-spawning (PoS) phases. Total and differential coelomocyte count, neutral red uptake capacity, indicative of phagocyte capacity, phagocytosis towards yeasts, antibacterial activity against staphylococcal strains and cytotoxic and hemagglutinating activities were evaluated using rabbit erythrocytes (RE) in male and female specimens.

\section{Materials and methods}

\subsection{Collection of animals, coelomocytes and sex determination}

A sample of about 200 mature sea urchins (Paracentrotus lividus), test diameter approximately $5 \mathrm{~cm}$, were collected by scuba diving at a depth of $10 \mathrm{~m}$ near a prairie of Posidonia oceanica in Gulf of Palermo areas not regarded polluted $\left(38^{\circ} 06.00^{\prime} \mathrm{N} ; 13^{\circ} 30.00^{\prime} \mathrm{E}\right)$ in a period between September and December, during a PrS (Visconti et al., 2008). Another sample of about 200 mature sea urchins with the same characteristics as the sample described above was collected in the same area between May and July, during a PoS (Dincer and Cakli, 2007). To avoid spawning, the sea urchins were kept in seawater at $15{ }^{\circ} \mathrm{C}$ until the arrival at the facility of the Department of Environmental Biology and Biodiversity. The animals were maintained in $120-\mathrm{L}$ aquaria filled with artificial seawater $(425 \mathrm{mM} \mathrm{NaCl} ; 9 \mathrm{mM} \mathrm{KCl}$; $9.3 \mathrm{mM} \mathrm{CaCl}_{2} ; 25.5 \mathrm{mM} \mathrm{MgSO}$; $23.0 \mathrm{mM} \mathrm{MgCl}$; $2.0 \mathrm{mM} \mathrm{NaHCO}$; $\mathrm{pH}$ 8.0) (ASW) at $12-15^{\circ} \mathrm{C}$, comparable to coastal temperatures, equipped with biological and physical filters, and they were fed with commercial invertebrate food (Azoo, Taikong Corp. Taiwan).

The coelomic fluid (CF) containing the total coelomocyte population was withdrawn by inserting the needle of a syringe, preloaded with a same amount of chilled anticoagulant consisting of isosmotic solution (20 mM Tris, $0.5 \mathrm{M} \mathrm{NaCl}$, pH 7.5) (ISO) enriched with $70 \mathrm{mM}$ EDTA (ISO-EDTA), through the peristomal membrane. After centrifugation with a swing-out rotor ( $900 \mathrm{~g}$ for $10 \mathrm{~min}$ at $4{ }^{\circ} \mathrm{C}$ ), the coelomocytes were washed two times in ISO-EDTA and resuspended at $5 \times 10^{6}$ cells/mL in ISO-EDTA. Aliquots of cell-free CF (FCF) were prepared by extracting the $\mathrm{CF}$ without anticoagulant solution and centrifuging it immediately ( $900 \mathrm{~g}$ for $10 \mathrm{~min}$ at $4{ }^{\circ} \mathrm{C}$ ) to remove the coelomocytes. FCF after dialysis (cellulose membrane tube MWCO 12,400) in ISO-Ca ${ }^{2+}$ was utilized for the cytotoxic and hemagglutination tests.

To determine the sex of the individual, after the bleeding procedure, $\mathrm{KCl} 0.5 \mathrm{M}$ dissolved in ISO was carefully injected into the internal cavity using a $1-\mathrm{mL}$ syringe with a $22-\mathrm{G}$ needle via the peristome wall or through one of the gonopores (Buznikov et al., 2003). Sex was judged by visual inspection of males and females releasing gametes. All experiments were carried out using the cells from 5 individuals of both genders without pooling. Sex determination was made only after the bleeding to avoid disturbing the animal.

\subsection{Gonadosomatic Index (\%)}

To determine the gonadosomatic index (GSI), 40 sea urchins, similar in size, of both genders and in both reproductive stages (PrS and PoS) were weighed. Then the gonads were scooped out and blotted to dryness on an absorbent towel for a few minutes to drain the coelomic fluid. Next they were weighed again with a precision of $1 \mathrm{mg}$. The GSI was calculated as a ratio of the gonad mass to the whole-body wet mass

Gonadosomatic index $=\frac{\text { Gonad weight }}{\text { Total weight }} \times 100$

\subsection{Preparation of coelomocyte lysate supernatant (CLS)}

Coelomocytes suspended in ISO-EDTA were centrifuged and suspended in $1 \mathrm{~mL}\left(1 \times 10^{7}\right.$ cells $)$ of ISO containing $10 \mathrm{mM}$ of $\mathrm{Ca}^{2+}$ (ISO- $\mathrm{Ca}^{2+}$ ), sonicated (Sonifier Branson, model B-15 Danbury, CT USA) for $1 \mathrm{~min}$ at $0{ }^{\circ} \mathrm{C}$ ( 1 pulse/s, $70 \%$ duty cycle) and centrifuged at $27,000 \mathrm{~g}$ for $30 \mathrm{~min}$ at $4{ }^{\circ} \mathrm{C}$ to remove any precipitate. The supernatant was exhaustively dialyzed against ISO- $\mathrm{Ca}^{2+}$, and sample aliquots were stored at $-20{ }^{\circ} \mathrm{C}$.

\subsection{Total coelomocyte count (TCC) and differential coelomocyte counts (DCC)}

Total coelomocyte counts (TCC) were made using a Neubauerimproved chamber under a light microscope (Leica DMLB equipped with a digital camera Leica DC 200, Germany) and dead cells were evaluated by using the eosin-y exclusion test ( $0.5 \%$ in ISO-EDTA). Values were corrected taking in account the dilution with anticoagulant.

The count values were the average number of coelomocytes observed in 10 microscopic fields. Fresh coelomocyte smear preparations were examined and coelomocytes were classified according to Matranga et al. (2006) and Smith et al. (2010) to evaluate the differential coelomocyte count (DCC). The percentages of phagocytes, uncolored spherulocytes, vibratile cells and red cells were calculated.

\subsection{Phagocytosis assay}

The phagocytosis assay was performed as previously reported (Manachini et al., 2011). Saccharomyces cerevisiae (baker's yeast, type II, Sigma-Aldrich Chemical Co., St. Louis, MO, USA) was used as target. Yeasts were prepared in distilled water at $0.25 \% \mathrm{w} / \mathrm{v}$ (approximately $1 \times 10^{8}$ yeast $/ \mathrm{mL}$ ), autoclaved for $15 \mathrm{~min}$, washed twice by centrifugation at $2000 \mathrm{~g}\left(5 \mathrm{~min}, 4{ }^{\circ} \mathrm{C}\right)$, and finally incubated for $2 \mathrm{~h}$ at $20^{\circ} \mathrm{C}$ with a solution of eosin-Y (4-bromo-fluorescein) to a final concentration of $0.5 \%$ in ISO plus $10 \mathrm{mM}$ of $\mathrm{CaCl}_{2}$ (ISO- $\mathrm{Ca}^{2+}$ ). After repeated washes, the yeasts were suspended to a final concentration of $0.125 \% \mathrm{w} / \mathrm{v}$ in $\left(\right.$ ISO- $\mathrm{Ca}^{2+}$ ).

To perform the phagocytosis assay, $200 \mu \mathrm{L}$ of a suspension $\left(6 \times 10^{5}\right.$ cells) of male or female coelomocytes were added to $100 \mu \mathrm{L}$ of yeast preparation in the same buffer $\left(2 \times 10^{7}\right.$ yeast $)$ and incubated in $1 \mathrm{~mL}$ plastic tubes under gentle stirring for $90 \mathrm{~min}$ at $20^{\circ} \mathrm{C}$. Then $50 \mu \mathrm{L}$ of a quenching solution (QS: $2 \mathrm{mg} / \mathrm{mL}$ trypan blue, $2 \mathrm{mg} / \mathrm{mL}$ crystal violet

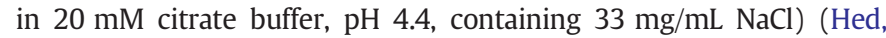
1986) were added and a drop of this suspension was smeared on a slide and examined under a Leica Diaplan Epifluorescence microscope (Leica, Wetzlar, Germany). Ten slides of each gender and reproductive stage were prepared (10 male PrS +10 male PoS and 10 female PrS + female PoS), and the phagocytosis present in each of 10 microscopic fields on each single slide at a magnification of $800 \times(\sim 200$ coelomocyte per slide) were then counted. The phagocytic activity was expressed as the percentage of coelomocytes ingested yeasts, while the phagocytic index was calculated as reported below:

Number of yeast engulfed divided by the number of the coelomocytes that engulfed yeasts. 


\subsection{Neutral Red Uptake (NRU)}

The method used in this study was a modified version of that used by Pipe et al. (1999). A suspension of living coelomocytes at $2 \times 10^{6}$ cells $/ \mathrm{mL}$ in ISO- $\mathrm{Ca}^{2+}$ of each sample was prepared. Aliquots of $100 \mu \mathrm{L}$ of $2.0,1.0$ and $0.1 \times 10^{5}$ cells/mL suspensions were pipetted into three replicate sterile microplate wells, and allowed to adhere for $30 \mathrm{~min}$. Aliquots $(10 \mu \mathrm{L})$ of $0.33 \%$ neutral red (Sigma-Aldrich) solution in ISO- $\mathrm{Ca}^{2+}$ were added to each well and the plate was incubated for $1 \mathrm{~h}$ at $10{ }^{\circ} \mathrm{C}$ in darkness. The cells were then centrifuged at $200 \mathrm{~g}$ for $5 \mathrm{~min}$ and washed three times in ISO-Ca ${ }^{2+}$. To each well $1 \%$ acetic acid in $50 \%$ ethanol was added to all wells for neutral red extraction. 15 min later, the absorbance of the extraction solution was read at $550 \mathrm{~nm}$. The result was expressed as O. D./mg of coelomocyte protein. The protein content was measured according to the method of Bradford as below reported.

\subsection{Cytotoxic assays}

\subsubsection{Target cells}

Rabbit erythrocytes (RE) provided by the "Istituto Zooprofilattico della Sicilia" (Palermo, Italy) were washed three times in phosphate buffered saline (PBS: $\mathrm{NaCl} 150 \mathrm{mM}, \mathrm{KH}_{2} \mathrm{PO}_{4} 146 \mathrm{mM}, \mathrm{Na}_{2} \mathrm{HPO}_{4}$ $0.8 \mathrm{mM}, \mathrm{KCl} 2.6 \mathrm{mM}, \mathrm{CaCl}_{2} \cdot 2 \mathrm{H}_{2} \mathrm{O} 0.9 \mathrm{mM}, \mathrm{MgCl}_{2} \cdot 6 \mathrm{H}_{2} \mathrm{O} 0.49 \mathrm{mM} \mathrm{pH}$ 7.4) by centrifuging at $400 \mathrm{~g}$ for $10 \mathrm{~min}$ at $4{ }^{\circ} \mathrm{C}$ and then suspended at $1 \%(\mathrm{v} / \mathrm{v})$ in ISO- $\mathrm{Ca}^{2+}$.

\subsubsection{Coelomocyte cytotoxic activity (CCA) assay}

The CCA was examined as described by Arizza et al. (2007). Briefly, $1 \times 10^{6}$ coelomocyte (effector cells, E) suspended in $200 \mu \mathrm{L}$ of ISO$\mathrm{Ca}^{2+}$ were mixed with $8 \times 10^{7}$ freshly prepared RE (target cells, T) in $200 \mu \mathrm{L}$ of $\mathrm{ISO}-\mathrm{Ca}^{2+}(\mathrm{E}: \mathrm{T}$ ratio $=1: 80)$ and doubly diluted to obtain the following E:T ratios: 1:40, 1:20, 1:10 and 1:5. The reaction mixture was incubated at $20^{\circ} \mathrm{C}$ for $30 \mathrm{~min}$. After centrifugation ( $400 \mathrm{~g}$ for $10 \mathrm{~min}$ at $4{ }^{\circ} \mathrm{C}$ ), the amount of the released hemoglobin present in the supernatant was estimated by reading the optical density (O. D.) by absorbance at $541 \mathrm{~nm}$. The hemolysis degree was registered according to the formula:

Hemolysis degree

O.D. measure release - O.D. spontaneous release

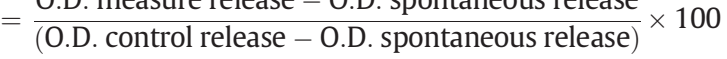

Complete hemoglobin release was obtained by preparing an erythrocyte suspension in distilled water at room temperature. A control erythrocyte suspension was prepared in ISO- $\mathrm{Ca}^{2+}$ and incubated under the same experimental conditions, and the hemoglobin release was measured (spontaneous release). Coelomocyte mortality in ISO$\mathrm{Ca}^{2+}$, under our experimental conditions, was less than $5 \%$, and spontaneous hemoglobin release from untreated erythrocytes never exceeded $5 \%$ of the total release (100\% erythrolysis).

\subsubsection{FCF hemolysis activity}

The FCF was dialyzed overnight against ISO- $\mathrm{Ca}^{2+}$ before being utilized for the tests. Suspensions of RE $\left(200 \mu \mathrm{L} 1 \%\right.$ in ISO-Ca $\left.{ }^{2+}\right)$ were added to an equal volume of FCF that was either undiluted or serially diluted with ISO- $\mathrm{Ca}^{2+}$. This mixture was incubated $60 \mathrm{~min}$ at $20^{\circ} \mathrm{C}$ with gentle agitation. Then the tubes were immediately centrifuged for 5 min at $750 \mathrm{~g}$ to pellet RE and debris. The optical density (O. D.) of the supernatant was determined at $541 \mathrm{~nm}$. Controls were performed incubating $200 \mu \mathrm{L}$ of RE suspension with PBS alone. Test erythrocytes, following the above procedure, were incubated in distilled water, and the resultant O. D., representing $100 \%$ lysis, was measured. Using the above control values, the corrected experimental O. D. was converted to percent lysis values using the formula reported above (2).

\subsection{Hemagglutinating activity}

Hemagglutinating activity (designated HA) was determined in 96-well round bottom microtiter plates using PBS containing $0.1 \%$ gelatin as a dilution medium (serial two-fold dilutions), and an equal volume of $1 \%$ RE in PBS. The samples of FCF and CLS were dialyzed overnight in PBS before the experiment. The microplate was incubated at $37{ }^{\circ} \mathrm{C}$ for $1 \mathrm{~h}$. The titer of hemagglutinating activity (designated HT) was expressed as the reciprocal of the highest dilution giving unequivocal agglutination judged by eye or with a low-power binocular microscope. The HT values, expressed as $\log _{2}$, were recorded as the average \pm SD of 10 different assays. Controls consisted of PBS samples to which FC was not added.

\subsection{Antimicrobial activity of 5-GC}

2.9.1. Preparation of gonadal $5 \mathrm{kDa}$ peptide fraction component (5-GC) A 5-kDa cationic peptide fraction was isolated from gonads (5-GC) by using an acidic extraction method that is an adaptation of that of Schillaci et al. (2010). The gonads from adult sea urchins $(6-8 \mathrm{~cm}$ diameter) were extracted gently with a spatula without contaminants, and placed in the extraction solution (w/v 35\%) consisting of glacial acetic acid $10 \%$. The tissue was homogenized on ice with a mechanical homogenizator (T50 Ultra-turrax IKA Germany) for $1 \mathrm{~min}$. The resulting homogenates were sonicated (Sonifier Branson, model B-15) for $5 \mathrm{~min}$ at $0{ }^{\circ} \mathrm{C}$ ( 1 pulse $/ \mathrm{s}, 70 \%$ duty cycle) and centrifuged at 27,000 $\mathrm{g}$ for $30 \mathrm{~min}$ at $4{ }^{\circ} \mathrm{C}$ to remove any precipitate and debris. After centrifugation the supernatants were collected, dried in a vacuum centrifuge (Maxi Dry Lyo, Heto Lab., Denmark) and solubilized in distilled water. To obtain the 5-GC fraction from gonads, the extracts were filtered through a membrane with a nominal size of $5 \mathrm{kDa}$ (Ultrafree-0.5 PBCC Centrifugal filter Unit; Amicon Millipore, MA, USA).

\subsubsection{Microbial strains and growth conditions and minimum inhibitory} concentrations (MIC)

Four Staphylococcus aureus strains of veterinary interest were isolated from milk samples. In particular, strain 657 was isolated from a milk sample from an individual sheep affected by mastitis, and strains 688, 700 and 702 were isolated from a bulk milk sample from a sheep flock.

MICs were determined by the previously described micro-method (Schillaci et al., 2005). Briefly, a series of solutions of 5GC was prepared with a range of concentrations from 2.5 to $0.07 \mu \mathrm{g} / \mathrm{mL}$ (obtained by two-fold serial dilution). The serial dilutions were made in MuellerHinton broth (Merck) in a 96-well plate; to each well $10 \mu \mathrm{L}$ of a bacterial suspension from a $24 \mathrm{~h}$ culture containing $\sim 1 \times 10^{6} \mathrm{cfu} \mathrm{mL}^{-1}$ corresponding to an optical density (O.D.) of 0.045 at $570 \mathrm{~nm}$, was added. The plate was incubated at $37^{\circ} \mathrm{C}$ for $24 \mathrm{~h}$; then, the MICs were determined by a microplate reader (ELX 800, Bio-Tek Instruments) as the lowest concentration of compound whose O.D., read at $570 \mathrm{~nm}$, was comparable with the negative control wells (broth only, without inoculum).

\subsection{Protein concentration}

Protein content was recorded with the method of Bradford (1976), and bovine serum albumin (BSA) as a standard.

\subsection{Statistical analysis}

Experimental data refer to measurements, performed in triplicate, of 5 specimens of both genders and from both sampling phases (PrS and PoS). For mean comparisons one-way ANOVA was performed followed by Tukey's post-test using SPSS software. In figures, data were presented as mean $\pm \mathrm{SD}$ and $p<0.05$. 


\subsection{Chemicals}

Unless otherwise reported, all chemicals were purchased from Sigma-Aldrich.

\section{Results}

\subsection{Gonadosomatic Index (\%)}

The gonad mass of sea urchins in the PrS and PoS differ significantly (Arafa et al., 2012). The gonadal index showed a high value of $14.76 \pm$ $1.56 \%$ in PrS, and then decreased to a value of $6.24 \pm 1.1 \%$ in PoS $(p<0.05)$ (data not showed).

\subsection{Total Coelomocyte Count (TCC) and Differential Coelomocyte Counts} (DCC)

The microscopic analysis, allowed us to easily identify the 4 main cell types and we estimated their number and ratios performing both a total (TCC) and differential (DCC) count. Though the TCC values were higher in PrS than PoS, they were not significantly higher. Moreover, although a slight decrement of the TCC from female to males was found both in PrS $\left(8.2 \pm 1.2 \times 10^{6} / \mathrm{mL}\right.$ and $7.3 \pm 1.7 \times 10^{6} / \mathrm{mL}$ respectively) and in PoS $\left(7.1 \pm 2.1 \times 10^{5} / \mathrm{mL}\right.$ and $6.8 \pm 2.7 \times 10^{5} / \mathrm{mL}$ respectively), the values did not vary statistically $(p>0.05)$. Interestingly the DCC analysis showed a significantly higher number of phagocytes in females in both phases (PrS: $6.6 \pm 0.9 \times 10^{6} / \mathrm{mL}$ and PoS: $5.7 \pm 0.5 \times 10^{6} / \mathrm{mL}, p<0.05$ ) as compared to males (PrS: $5.6 \pm 0.5 \times 10^{6} / \mathrm{mL}$ and PoS: $5.2 \pm 0.3 \times 10^{6} / \mathrm{mL}$ ) as well as in the number of the uncolored spherulocytes (PrS: $0.7 \pm$ $0.1 \times 10^{6} / \mathrm{mL}$ and PoS: $0.6 \pm 0.2 \times 10^{6} / \mathrm{mL}, p<0.05$ ) in females as compared to males (PrS: $0.6 \pm 0.2 \times 10^{6} / \mathrm{mL}$ and PoS: $0.5 \pm 0.5 \times 10^{6} / \mathrm{mL}$ ) (Fig. 1). Colored spherulocytes and vibratile cells of the two genders and in both phases showed no significant differences.

\subsection{Phagocytosis assay}

In $P$. lividus, the phagocytes type is the largest component ( $~ 80 \%)$ of the coelomocyte population. The main activity related to immunity is phagocytic activity. When the sea urchin phagocytes were mixed with non-self particles such as yeast, they were able to engulf them, to the point of filling their whole cytoplasm (Fig. 4 inset). The data obtained from phagocytosis assays show generally higher female activity than male. PrS females show a higher phagocytic activity $(\sim 14 \%)$ than PrS males $(\sim 10 \%) \quad(p<0.05)$. The same trend was obtained comparing phagocytic activity of PoS females and males $(\sim 13 \%$ and $\sim 8 \%$ respectively. $p<0.05)$. But the phagocytic index did not show any significant differences (Fig. 2). Comparison of the data of the PrS and PoS specimens showed no significant differences in phagocytosis activity or phagocytic index (Fig. 2).

\subsection{Neutral red uptake (NRU)}

The treatment of coelomocytes with neutral red solution (NR) revealed that both phagocytes and uncolored spherulocytes can incorporate the dye (Fig. 3 inset respectively A and B). The differing capability of hemocytes to assume NR is shown in Fig. 3 for each coelomocyte concentration, sampling period and gender. Indeed, a significant increase $(p<0.01)$ in dye uptake was observed in hemocytes $\left(1 \times 10^{5}\right.$ cells $\left./ \mathrm{mL}\right)$

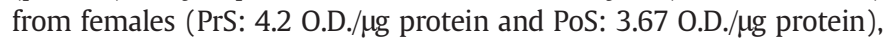

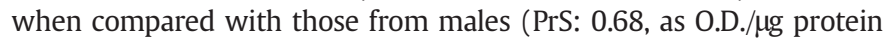

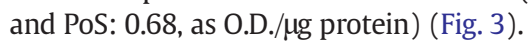

\subsection{Cytotoxic assays}

The coelomocytes of both genders from two phases (PrS and PoS) were capable of killing RE at all effector-target ratios (Fig. 4). Female coelomocytes however, at an E:T ratio of 1:20, lysed RE more vigorously (PrS: $51.2 \pm 2.2$ and PoS: $48.6 \pm 2.5 p<0.001$ respectively) than male coelomocytes (PrS: $15.2 \pm 2.1$ and PoS: $14.4 \pm 3.1$ respectively). Although the PrS female coelomocytes were more active (about $15 \%$ ) than those in PoS at each E:T ratio, no significant differences were detectable $(p>0.05)$.

Coelomocytes contain and can release cytolytic molecules (Arizza et al., 2007) in the coelomic fluid (CF). In Fig. 5, the different hemolytic degrees of FCF between females and males of both phases (PrS and PoS) are shown. The PrS-FCF $(80 \mu \mathrm{g} / \mathrm{mL})$ from females have a significantly $(p<0.001)$ higher hemolytic activity $(79.2 \pm 9.1)$ compared to PrS males $(54.2 \pm 6.5)$. The same trend was detectable using the PoS-FCF but at a slightly lower level.

\subsection{Hemagglutinating activity}

In $P$. lividus the hemagglutinating activity was present both in the dialyzed CLS and FCF. They were able to agglutinate rabbit red blood

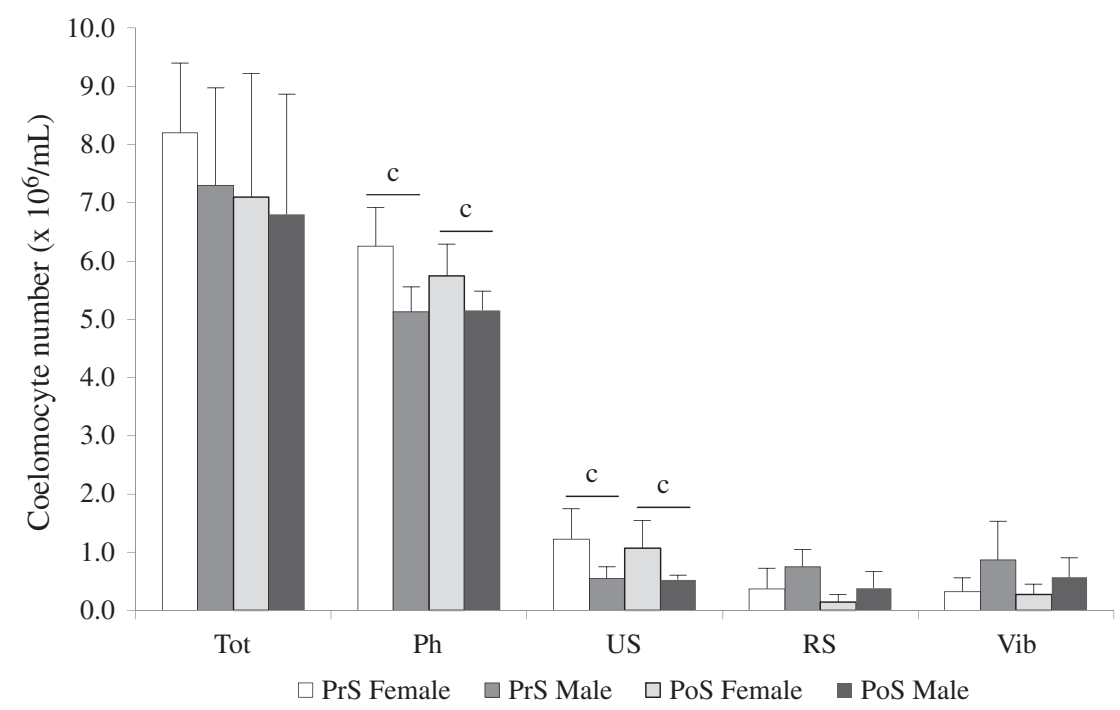

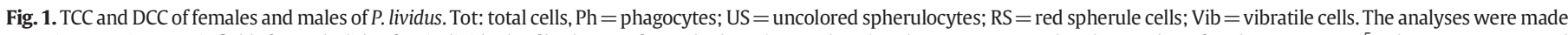

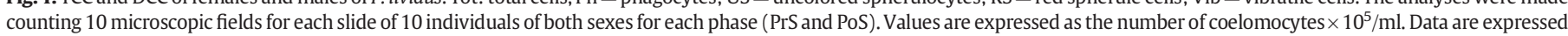
as the mean value $\pm S D$ of five separate experiments for each sex, performed in triplicate. Statistical analysis by one-way ANOVA with Tukey's post-test. $c=p<0.05$. 


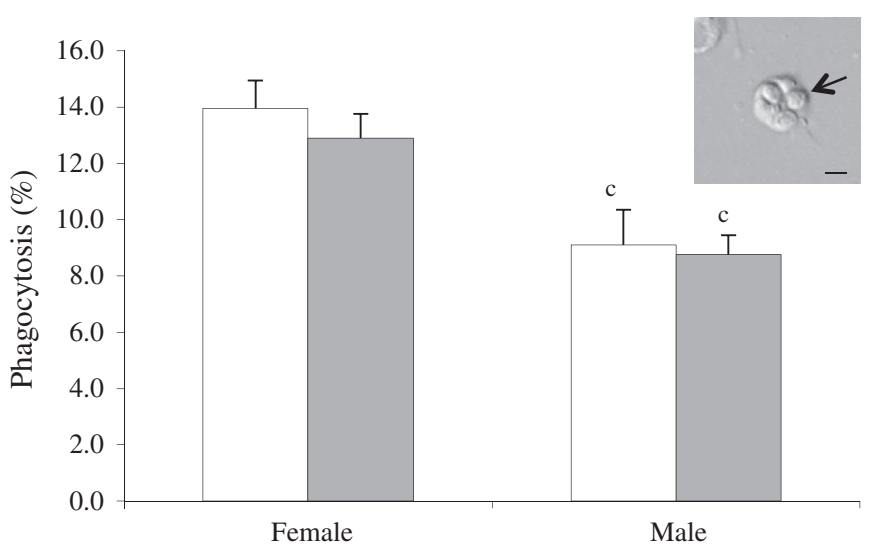

Fig. 2. Phagocytosis (number of cells that ingested yeast/coelomocyte number) of $P$. lividus phagocytes of both sexes (5 specimens for each genders) of animals sampled in $\operatorname{PrS} \square$ and in PoS $\square$. Phagocytic cells were incubated with yeast and phagocytosis was evaluated by means of observation under a Nomarski contrast face light microscope. Inset: living phagocyte with 3 yeast ingested. Arrow $=$ ingested yeast. $\operatorname{Bar}=7.5 \mu \mathrm{m}$. Data are expressed as the mean value $\pm S D$ of five separate experiments for each sex, performed in triplicate. Statistical analysis by one-way ANOVA with Tukey's post-test. $c=p<0.05$.

cells in a dose-dependent manner (data not shown). In Table 1 we report the differential agglutinating activity in the CLS and FCF from the two genders, using animals sampled in PrS and PoS. The agglutinating activity of CLS was significantly higher $\left({ }^{*} p<0.05\right)$ than FCF in all experiments. Moreover the females showed significantly higher hemagglutinating activity $(\mathrm{C}=p<0.05)$ compared to males in all the experiments. Finally the results from both genders in PrS were significantly higher $(c=p<0.05)$ than those in PoS ones (Table 1$)$.

\subsection{Antimicrobial activity of 5-GC}

Antibacterial activity against staphylococcal strains was disclosed by assaying an acid extract from the gonadal tissue performed to separate cationic peptides $<5 \mathrm{kDa}$ (5-GC). The activity expressed as minimum inhibitory concentration (MIC) is listed in Table 2. The concentration of 5-GC from both sexes in the different sampling phases ranges from 2.5 to $0.07 \mu \mathrm{g} / \mathrm{mL}$. The peptides were inactive against staphylococcal strains at the maximum tested concentration of $2.5 \mu \mathrm{g} / \mathrm{mL}$, except against the strain S. aureus 688 where female MICs of 1.25 (PrS and PoS female) were significantly lower than the male values of $2.50 \mu \mathrm{g} / \mathrm{mL}$ (both PrS and PoS males).

\section{Discussion}

Until now, there have been few studies demonstrating gender differences in the immune responses of invertebrates and these have regarded mainly arthropods or molluscs. Rheins and Karp (1985) found enhanced and prolonged immune responses in female Periplaneta americana cockroaches immunized with honeybee venom. Gray (1998) demonstrated that females of house crickets Acheta domesticus are less susceptible than males to experimental infection with Serratia liquefaciens. In male shrimp of Streptocephalus dichotomus the phenol oxidase activity in the hemolymph is only one-third of that of females (Radhika et al., 1998). Finally Matozzo and Marin (2010) demonstrated by testing neutral red uptake that females of Ruditapes philippinarum had more active immune defense reactions, especially during the prespawning period.

Previous studies of echinoderms showed that immune activities such as haemolysis in the coelomic fluid of sea stars did not vary between the sexes (Canicatti, 1989). We show that such a difference can indeed be found: female $P$. lividus specimens had a significantly higher level of immune activity than male specimens, in regard to both cellular (tissue) and humoral (coelomic fluid) reactions. This increased defense activity was not only present in the period between September and December, when the specimens of $P$. lividus are in a pre-spawning phase, but significant differences, though at a lower level, were also present in the period between May and July, when the animals are in post-spawning stage.

The body cavity of echinoderms is filled with coelomic fluid that contains coelomocytes that mediate responses to wounding and microbial infections by undergoing reactions such as opsonisation, coagulation, encapsulation and phagocytosis. Their number (TCC) and ratio (DCC) are important parameters in understanding the state of an organism and its ability to defend itself.

The literature reports that the coelomic fluid of $P$. lividus contains four main coelomocyte types including about $~ 80 \%$ phagocytes $(\mathrm{Ph})$, 8\% uncolored spherulocytes (US), 5\% red spherule cells (RS) and $\sim$ \% vibratile cells (Vib). Each of these coelomocyte types possesses

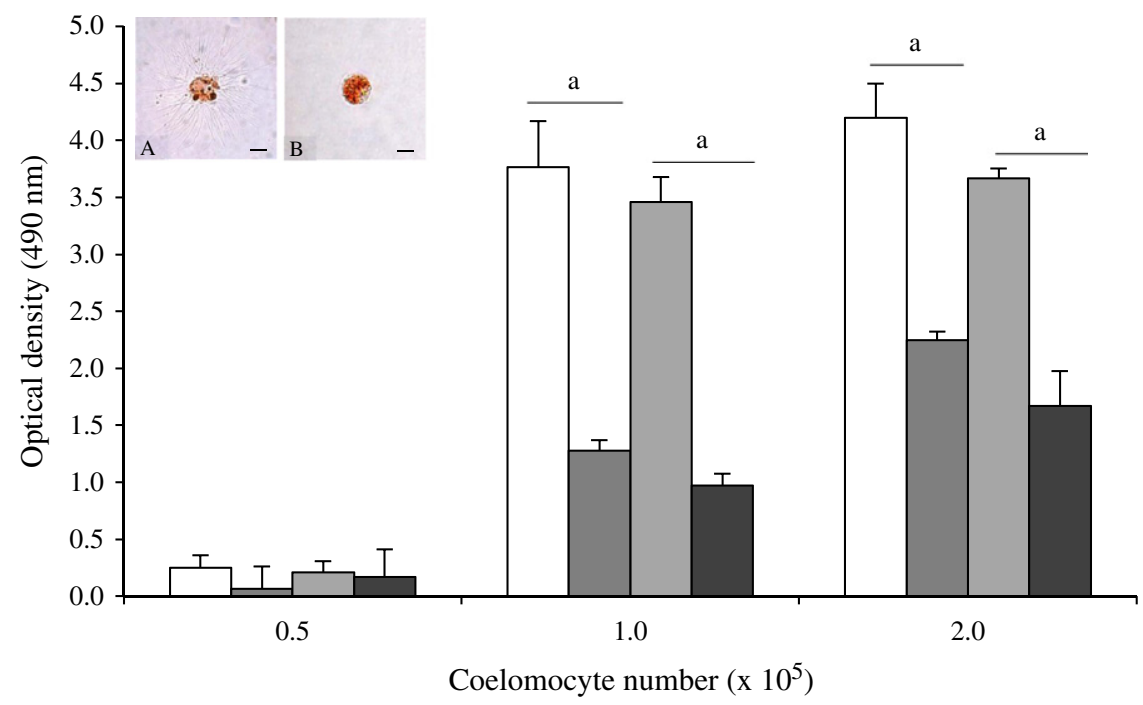

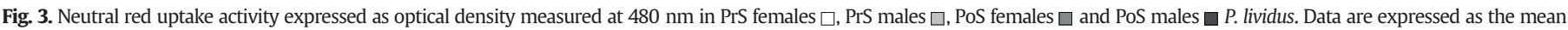

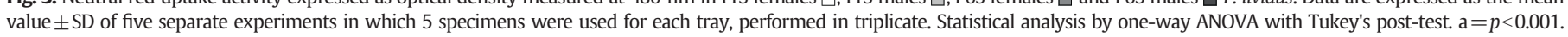
Inset shows living coelomocytes with neutral red incorporation. A: spherulocytes; B: phagocyte. Bar $=10 \mu \mathrm{m}$. 


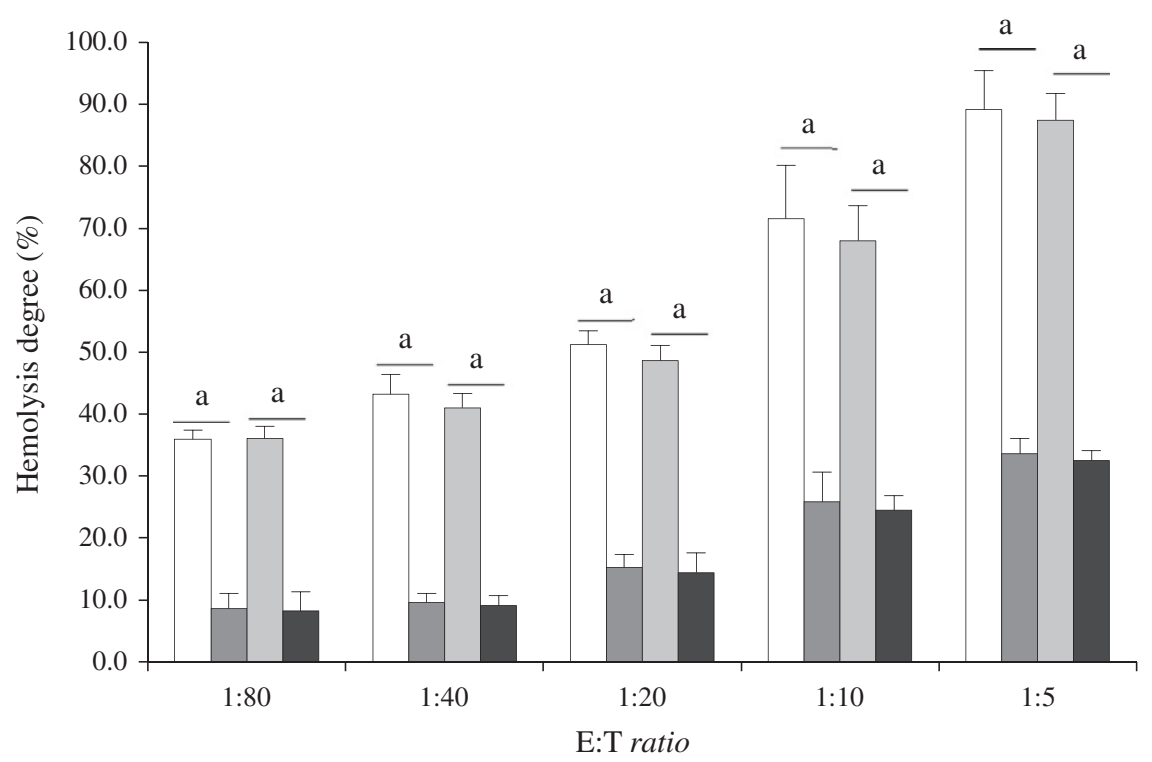

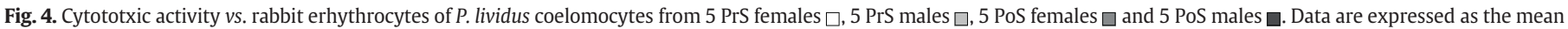
value $\pm S D$ of five separate experiments for each sex, performed in triplicate. Statistical analysis by one-way ANOVA with Tukey's post-test. $a=p<0.001$.

a unique cell shape, cell motility and physiological function (Arizza et al., 2007; Li et al., 2010).

In echinoderms it has been found that hypoxia together with wounding trauma induced an increment of TCC and HSP70 expression in the coelomocytes (Holm et al., 2008). Moreover, enriched red cells population was found in the individuals exposed to polluted environments (Matranga et al., 2000; Pinsino et al., 2007). In this study we compared the number of the coelomocytes (TCC) and their ratio (DCC) in both P. lividus genders during the two sampling periods (PrS and PoS), and the data clearly indicate that although the number of coelomocytes was lower in males, there were no significant gender-based differences in the total coelomocyte counts. These findings are in agreement with data from shellfish, where males and females have equivalent values of total hemocyte count (Matozzo and Marin, 2010), but in contrast with those from insects.
In fact, in almost all species examined, females had greater average hemocyte counts than males in the absence of infection; males, but not females, showed an increased concentration of hemocytes in the presence of infection (Zuk, 1990; Zuk and McKean, 1996; Yourth et al., 2002; Zuk et al., 2004).

Our data still show that although there were no significant differences in the number of total coelomocytes between the genders, the sexes showed significant differences in the DCC and specifically, in the quantity of phagocytes and uncoloured spherulocytes in PrS and PoS.

Humoral and cellular cytotoxicity together with phagocytosis are the main defense reactions of the natural immune system of sea urchins. The cytotoxic activity can be found in the coelomic fluid or performed by uncoloured spherulocytes, whereas phagocytosis is carried out by phagocytes. In the present study humoral and cellular cytotoxic activity, and phagocytic activity was found higher in female

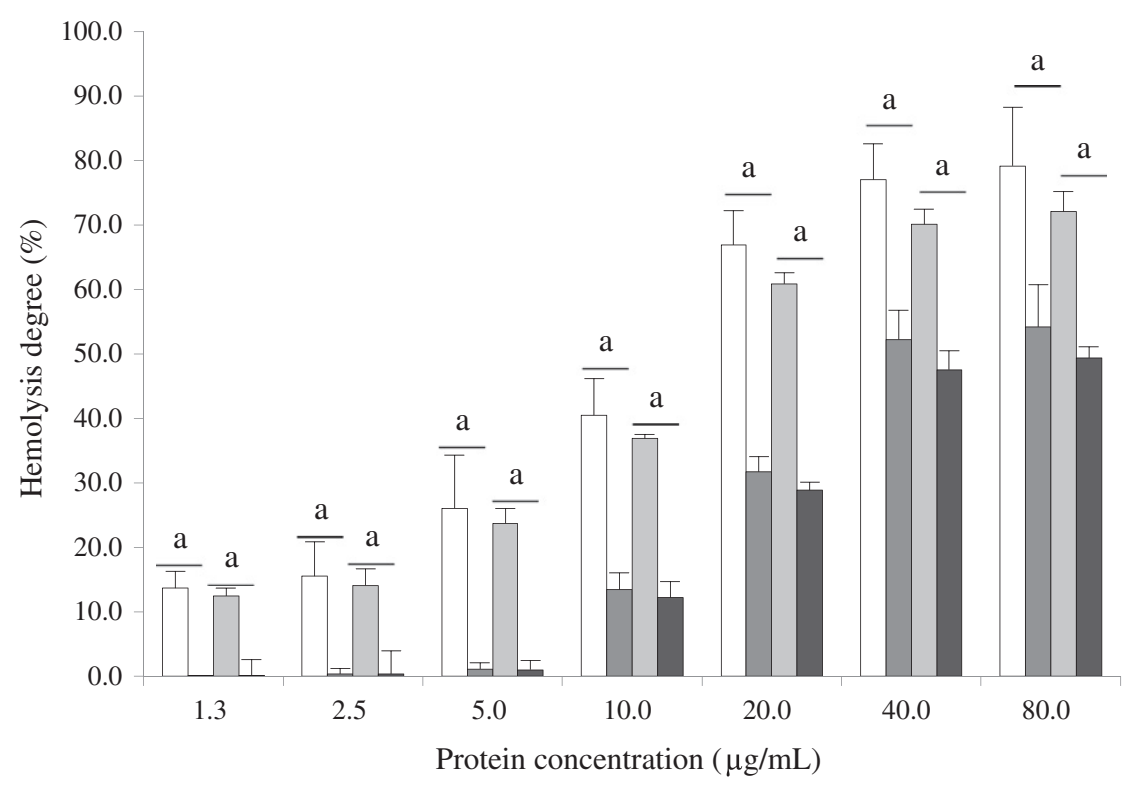

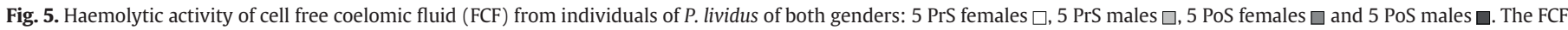

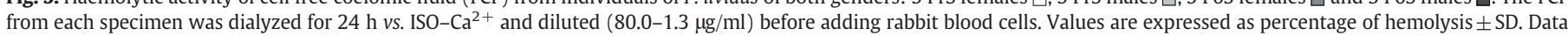
are expressed as the mean value of five separate experiments for each, performed in triplicate. Statistical analysis by one-way ANOVA with Tukey's post-test. $a=p<0.001$. 
Table 2

Antimicrobial activity of acid extract from gonads of both $P$. lividus genders ( 5 PrS and 5 PoS females and 5 PrS and 5 PoS males). Values are expressed in $\mu \mathrm{g} / \mathrm{ml}$ for all strains tested. Data are expressed as the mean value $\pm S D$ of five separate experiments for each sex, performed in triplicate. Statistical.

\begin{tabular}{|c|c|c|c|c|}
\hline \multirow[t]{3}{*}{ S. aureus strains } & \multicolumn{4}{|c|}{ 5-GC MIC values $\mu \mathrm{g} / \mathrm{mL}$} \\
\hline & \multicolumn{2}{|l|}{ Female } & \multicolumn{2}{|l|}{ Male } \\
\hline & PrS & PoS & $\operatorname{PrS}$ & PoS \\
\hline 657 & n.a. & n.a. & n.a. & n.a. \\
\hline 688 & $1.25^{(\mathrm{c})}$ & $1.25^{(\mathrm{c})}$ & 2.50 & 2.50 \\
\hline 700 & n.a. & n.a. & n.a. & n.a. \\
\hline 702 & n.a. & n.a. & n.a. & n.a. \\
\hline
\end{tabular}

specimens of $P$. lividus, with respect to that of males. Conversely, no statistically significant variations in phagocytic index were found between female and male sea urchins. No statistically significant differences in phagocytic activity or phagocytosis index were recorded for either gender between the two periods PrS and PoS.

Neutral red uptake (NRU) is used to evaluate the endocytic activity of the cells (Cajaraville et al., 1996). The lipophilic dye can permeate the cell membrane quite freely (Zhang et al., 2006) and accumulates intracellularly in lysosomes. In our NRU experiments it was evident that neutral red (inset A Fig. 3) was internalized by phagocytes as well as acquired by granules of uncoloured spherulocytes (inset B Fig. 3). In the present study, a significant increase in the NRU activity was found in cells from females with respect to males. Since the phagocytic index do not vary significantly between the genders in any stages, the higher values of NRU found in females could not be imputed to a greater capacity to internalize the dye, but to a higher number of cells including phagocytes and uncolored spherulocytes that were more numerous in female rather than in male coelomic fluid.

Paracentrotus lividus possesses agglutinins that are capable of binding vertebrate cells such as rabbit erythrocytes (Cervello et al., 1996). Agglutinins play an important role in non-specific defense mechanisms functioning as key molecules in immune responsiveness and augmenting coelomocyte functions in host defense. Agglutinins are stored in the coelomocytes and can be released in the coelomic fluid (Cervello et al., 1996). Here we evaluated the agglutination ability to bind rabbit erythrocytes present in both the coelomic fluid and the coelomocyte lysate supernatant. We report that females had a significantly higher hemagglutinating activity than males in the PrS period. The higher activity found in this period could be explained by the agglutinating activity exhibited by vitellogenin (Vtg). This molecule is thought to be the precursor of yolk proteins which are accumulated in the maturing egg. In the sea urchin, Vtg has an intriguing localization in the coelomic fluid of both male and female individuals (Shyu et al., 1986; Cervello and Matranga, 1989). We have previously shown that vitellogenin is contained in the uncolored spherulocytes of both sexes of P. lividus and can be released in the coelomic fluid under stressful conditions (Cervello et al., 1994). During the

\section{Table 1}

Hemagglutinating activity of cell free coelomic fluid (FCF) and coelomocyte supernatant lysate (CLS) of female and male from P. lividus specimens sampled in PrS and PoS. Data are expressed as the mean value \pm SD of five separate experiments for each tray, performed in triplicate. Statistical analysis by one-way ANOVA with Tukey's post-test. ${ }^{*}=p<0.05$ significance degree between CLS and FCF; C $=p<0.05$ significance degree between female and male; $c=p<0.05$.

\begin{tabular}{lll}
\hline Sample & \multicolumn{3}{l}{ Hemagglutinating activity vs RE $\left(\log _{2} \pm \mathrm{SD}, n=5\right)$} \\
\cline { 2 - 3 } & Female & Male \\
\hline PrS-CLS & $7.2 \pm 0.4^{(*)},(\mathrm{C}),(\mathrm{c})$ & $5.6 \pm 2.3^{(*)},(\mathrm{c})$ \\
PrS-FCF & $6.4 \pm 1.4^{(\mathrm{C}),(\mathrm{c})}$ & $5.0 \pm 1.41^{(\mathrm{c})}$ \\
PoS-CLS & $\left.6.0 \pm 0.8^{(*)}\right)^{(\mathrm{C}),}$ & $5.4 \pm 1.1^{(*)}$, \\
PoS-FCF & $5.4 \pm 1.1^{(\mathrm{C})}$ & $5.0 \pm 2.0$ \\
\hline
\end{tabular}

PoS, the animals have now completed the maturation of eggs and have utilized much of the Vtg available from coelomocytes and CF. This could cause the significant decrease of hemagglutinating titre found both in the PoS-FCF and PoS-CLS of females compared with the PrS-FCF and PrS-CLS $(p<0.05)$.

Antimicrobial peptides (AMPs) are another kind humoral immune effector molecule of natural immunity in invertebrates. They have been identified both in plasma and in various blood cells and their distribution in the host can be site-specific or systemic. They protect host organisms against a variety of infections, but they also modulate immunity (Hancock and Diamond, 2000; Zasloff, 2002; Hancock et al., 2006).

In echinoderms, the coelomocyte lysate or coelomic fluid show antimicrobial activity. Echinus esculentus show bactericidal activity against marine Pseudomonas sp. in the coelomic fluid (Wardlaw and Unkles, 1978). Gerardi et al. (1990) found that the highest bacterial growth inhibition against several Vibrio sp. is shown by phagocytes and red spherule cells of $P$. lividus. Stabili et al. (1996) also discovered antibacterial activity against $V$. alginolyticus in celomocyte lysates and the celomic fluid of P. lividus. Moreover Stabili and Canicatti (1994) showed that gonads of $P$. lividus contain and release antibacterial activity in the seminal plasma. Recently Li et al. (2008), for the first time, found two novel antibacterial peptides in Strongylocentrotus droebrachiensis coelomocyte extract. Experiment using the cloned antibacterial peptides showed that they were active against $L$. anguillarum and $S$. aureus and their antibacterial activity was linked by intracellular killing mechanisms (Li et al., 2010). Coelomocyte acid extract of $P$. lividus contains a small peptides $(<5 \mathrm{kDa})$, showing an anti-staphylococcal biofilm activity (Schillaci et al., 2010). In this study the authors performed analyses in order to determine whether any antibacterial activity, represented by small $(<5 \mathrm{kDa})$ peptide molecules, was present in the gonadal tissue of female and male specimens of $P$. lividus. We report that the protein component less than $5 \mathrm{kDa}$ from the gonadal tissue of both sexes demonstrates specific activity against $S$. aureus strain 688 and the MIC values revealed that the acidic extract from female gonads was able to kill bacterial cells more efficiently that from males. No significant differences were seen between the 5-GC of both sexes from specimens collected during PrS and PoS.

Studies on stressor impacts of gametogenesis and spawning and on the modulating effects on the immune functions are few and limited to molluscs (Schleder et al., 2008; Li et al., 2009; Matozzo and Marin, 2010) and crustaceans (Liu et al., 2007; Travers et al., 2008). Here, for the first time, the immune-surveillance levels in $P$. lividus in pre- and post-spawning phases were evaluated.

The differences between the sexes as regards immune ability in vertebrates can be explained by the modulating activity of sexual hormones. According to Grossman (1989), hormonal interactions based on androgen hormones lead to lower immunological responsiveness in males. These androgen hormones are subtracted as resources from the immune system in order to develop sexual signal traits. This model of a resource-based trade-off between sexual signals and immunecompetence should apply to all organisms possessing both immune system and sexual signal traits, vertebrates as well as invertebrates.

We do not know which $P$. lividus factors can make a difference in immune responses between the two genders, but the possibility exists that they could be related to hormones regulating both immune functions and sexual signal expression. In this respect Barbaglio et al. (2007) reported that the concentration of sex hormones varies during the $P$. lividus reproductive cycle. In males and females, testosterone reached the maximum level at the post-spawning stage and a minimum one at the pre-spawning stages. In female, the estradiol level was generally higher than testosterone, and no pre- and post-spowining variations were found. Since our data did not show any significant differences between pre and post-spawning stages in both sexes, the possibility exist that testosterone is not related to the examined cellular and humoral immune activities. On the contrary, these activities enhanced in females could be related to the estradiol levels. 
The differences in immune functions reflected in our data on female and male specimens of $P$. lividus can be explained more easily by focusing on the different composition of coelomocyte populations of the two genders. The number of phagocytes and uncolored spherulocytes were higher in females in both pre- and post-spawning periods. These two cellular types are responsible for most of the cell-mediated immune activity in sea urchins: phagocytes display phagocytic activity associated with clearance of bacteria, xenogeneic cells, foreign particles and proteins, both in vivo and in vitro (Gross et al., 1999); they contain and release agglutinins (Cervello et al., 1996) and have also been implicated in encapsulation and graft rejection responses, as well as cytolytic/ cytotoxic reactions (Coffaro and Hinegardner, 1977; Bertheussen, 1979); colorless spherule cells contain and can release cytolytic molecules and their activity is augmented by the presence of phagocytes (Arizza et al., 2007).

We can exclude that the above reported differences may be related to inconsistent sampling because the animals were all taken from the same area during the same period of pre- and post-spawning stages.

These results, according to Matozzo and Marin (2010), could indicate that although females of $P$. lividus during the pre-spawning period use most of their energy budget for oogenesis, they nevertheless present a higher level of immune surveillance to combat the possible adverse effects of pathogens. Thus, almost all the remaining energy is used to increment the number of immunocytes while probably subtracting resources from somatic growth. Further studies are needed to clarify the differences in immune responses of males and females during the sea urchin's biological growth and resting stages. Finally, this study brings to light an important recommendation: reproductive period and sex-related differences should be taken into consideration when studying cellular immune response, particularly when coelomocyte pools are used.

\section{Acknowledgments}

This work was supported by research grants from the MIUR. We thank Dr. Maria Grazia Brunone and Dr. Vincenzo Merlo for the excellent technical assistance provided. We greatly appreciated the assistance in statistical analysis provided by Dr. Daniela Campobello.

\section{References}

Adamo, S.A., 2004. Estimating disease resistance in insects: phenoloxidase and lysozymelike activity and disease resistance in the cricket Gryllus texensis. J. Insect Physiol. 50, 209-216.

Andersson, M.B., 1994. Sexual Selection. Princeton University Press, Princeton, N.J.

Arafa, S., Chouaibi, M., Sadok, S., El Abed, A., 2012. The influence of season on the gonad index and biochemical composition of the sea urchin Paracentrotus lividus from the Golf of Tunis. ScientificWorldJournal 2012, 815935.

Arizza, V., Giaramita, F.T., Parrinello, D., Cammarata, M., Parrinello, N., 2007. Cell cooperation in coelomocyte cytotoxic activity of Paracentrotus lividus coelomocytes. Comp. Biochem. Physiol. A Mol. Integr. Physiol. 147, 389-394.

Barbaglio, A., Sugni, M., Di Benedetto, C., Bonasoro, F., Schnell, S., Lavado, R., Porte, C., Candia Carnevali, D.M., 2007. Gametogenesis correlated with steroid levels during the gonadal cycle of the sea urchin Paracentrotus lividus (Echinodermata: Echinoidea). Comp. Biochem. Physiol. A Mol. Integr. Physiol. 147, 466-474.

Bateman, A.J., 1948. Intra-sexual selection in Drosophila. Heredity (Edinb) 2, 349-368.

Bertheussen, K., 1979. The cytotoxic reaction in allogeneic mixtures of echinoid phagocytes. Exp. Cell Res. 120, 373-381.

Bradford, M.M., 1976. A rapid and sensitive method for the quantitation of microgram quantities of protein utilizing the principle of protein-dye binding. Anal. Biochem. $72,248-254$.

Butterworth, M., McClellan, B., Allansmith, M., 1967. Influence of sex in immunoglobulin levels. Nature 214, 1224-1225.

Buznikov, G.A., Slotkin, T.A., Lauder, J.M., 2003. Sea Urchin Embryos and Larvae as Biosensors for Neurotoxicants, Current Protocols in Toxicology. Wiley \& Sons Inc. (24).

Cajaraville, M.P., Olabarrieta, I., Marigomez, I., 1996. In vitro activities in mussel hemocytes as biomarkers of environmental quality: a case study in the Abra Estuary (Biscay Bay). Ecotoxicol. Environ. Saf. 35, 253-260.

Canicatti, C., 1989. Evolution of the lytic system in Echinoderms. 2. Naturally-occurring hemolytic-activity in Marthasterias-Glacialis (Asteroidea) celomic fluid. Comp. Biochem. Physiol. A Comp. Physiol. 93, 587-591.

Canicatti, C., 1991. Binding properties of Paracentrotus lividus (Echinoidea) hemolysin. Comp. Biochem. Physiol. A Comp. Physiol. 98, 463-468.
Cervello, M., Arizza, V., Cammarata, M., Matranga, V., Parrinello, N., 1996. Properties of sea urchin coelomocyte agglutinins. Ital. J. Zool. 63, 353-356.

Cervello, M., Arizza, V., Lattuca, G., Parrinello, N., Matranga, V., 1994. Detection of vitellogenin in a subpopulation of sea urchin coelomocytes. Eur. J. Cell Biol. 64, 314-319.

Cervello, M., Matranga, V., 1989. Evidence of a precursor-product relationship between vitellogenin and toposome, a glycoprotein complex mediating cell adhesion. Cell Differ. Dev. 26, 67-76.

Chia, F.S., Xing, J., 1996. Echinoderm coelomocytes. Zool. Stud. 35, 231-254.

Coffaro, K.A., Hinegardner, R.T., 1977. Immune response in the sea urchin Lytechinus pictus. Science 197, 1389-1390.

Dincer, T., Cakli, S., 2007. Chemical composition and biometrical measurements of the Turkish sea urchin (Paracentrotus Lividus, Lamarck, 1816). Crit. Rev. Food Sci. Nutr. 47, 21-26.

Fedorka, K.M. Zuk, M., Mousseau, T.A., 2004. Immune suppression and the cost of reproduction in the ground cricket, Allonemobius socius. Evolution 58, 2478-2485.

Gerardi, P., Lassegues, M., Canicatti, C., 1990. Cellular-distribution of sea-urchin antibacterial activity. Biol. Cell 70, 153-157.

Gray, D.A., 1998. Sex differences in susceptibility of house crickets, Acheta domesticus, to experimental infection with Serratia liquefaciens. J. Invertebr. Pathol. 71, 288-289.

Gross, P.S., Al-Sharif, W.Z., Clow, L.A., Smith, L.C., 1999. Echinoderm immunity and the evolution of the complement system. Dev. Comp. Immunol. 23, 429-442.

Gross, P.S., Clow, L.A., Smith, L.C., 2000. SpC3, the complement homologue from the purple sea urchin, Strongylocentrotus purpuratus, is expressed in two subpopulations of the phagocytic coelomocytes. Immunogenetics 51, 1034-1044.

Grossman, C., 1989. Possible underlying mechanisms of sexual dimorphism in the immune response, fact and hypothesis. J. Steroid Biochem. 34, 241-251.

Hancock, R.E., Brown, K.L., Mookherjee, N., 2006. Host defence peptides from invertebratesemerging antimicrobial strategies. Immunobiology 211, 315-322.

Hancock, R.E., Diamond, G., 2000. The role of cationic antimicrobial peptides in innate host defences. Trends Microbiol. 8, 402-410.

Hed, J., 1986. Methods for distinguishing ingested from adhering particles. Methods Enzymol. 132, 198-204.

Hibino, T., Loza-Coll, M., Messier, C., Majeske, A.J., Cohen, A.H., Terwilliger, D.P. Buckley, K.M., Brockton, V., Nair, S.V., Berney, K., Fugmann, S.D., Anderson, M.K. Pancer, Z., Cameron, R.A., Smith, L.C., Rast, J.P., 2006. The immune gene repertoire encoded in the purple sea urchin genome. Dev. Biol. 300, 349-365.

Holm, K., Hernroth, B., Thorndyke, M., 2008. Coelomocyte numbers and expression of HSP70 in wounded sea stars during hypoxia. Cell Tissue Res. 334, 319-325.

Kudriavtsev, I.V., Polevshchikov, A.V., 2004. Comparative immunological analysis of echinoderm cellular and humoral defense factors. Zh. Obshch. Biol. 65, 218-231.

Kurtz, J., Sauer, K.P., 2001. Gender differences in phenoloxidase activity of Panorpa vulgaris hemocytes. J. Invertebr. Pathol. 78, 53-55.

Kurtz, J., Wiesner, A., Gotz, P., Sauer, K.P., 2000. Gender differences and individual variation in the immune system of the scorpionfly Panorpa vulgaris (Insecta: Mecoptera). Dev. Comp. Immunol. 24, 1-12.

Li, C., Blencke, H.M., Smith, L.C., Karp, M.T., Stensvag, K., 2010. Two recombinant peptides, SpStrongylocins 1 and 2, from Strongylocentrotus purpuratus, show antimicrobial activity against Gram-positive and Gram-negative bacteria. Dev. Comp. Immunol. 34, 286-292.

Li, C., Haug, T., Styrvold, O.B., Jorgensen, T.O., Stensvag, K., 2008. Strongylocins, nove antimicrobial peptides from the green sea urchin, Strongylocentrotus droebachiensis. Dev. Comp. Immunol. 32, 1430-1440.

Li, Y., Qin, J.G., Li, X.X., Benkendorff, K., 2009. Monthly variation of condition index, energy reserves and antibacterial activity in Pacific oysters, Crassostrea gigas, in Stansbury (South Australia). Aquaculture 286, 64-71.

Liu, W.J., Chang, Y.S., Wang, A.H., Kou, G.H., Lo, C.F., 2007. White spot syndrome virus annexes a shrimp STAT to enhance expression of the immediate-early gene ie1. J. Virol. 81, 1461-1471.

Manachini, B., Arizza, V., Parrinello, D., Parrinello, N., 2011. Hemocytes of Rhynchophorus ferrugineus (Olivier) (Coleoptera: Curculionidae) and their response to Saccharomyces cerevisiae and Bacillus thuringiensis. J. Invertebr. Pathol. 106, 360-365.

Matozzo, V., Marin, M.G., 2010. First evidence of gender-related differences in immune parameters of the clam Ruditapes philippinarum (Mollusca, Bivalvia). Mar. Biol. 157, 1181-1189.

Matranga, V., Pinsino, A., Celi, M., Di Bella, G., Natoli, A., 2006. Impacts of UV-B radiation on short-term cultures of sea urchin coelomocytes. Mar. Biol. 149, 25-34.

Matranga, V., Toia, G., Bonaventura, R., Muller, W.E., 2000. Cellular and biochemical responses to environmental and experimentally induced stress in sea urchin coelomocytes. Cell Stress Chaperones 5, 113-120.

Moller, A.P., Sorci, G., Erritzoe, J., 1998. Sexual dimorphism in immune defense. Am. Nat. 152, 605-619.

Moore, S.L., Wilson, K., 2002. Parasites as a viability cost of sexual selection in natural populations of mammals. Science 297, 2015-2018.

Pancer,Z., 2000. Dynamic expression of multiple scavenger receptor cysteine-rich genes in coelomocytes of the purple sea urchin. Proc. Natl. Acad. Sci. U. S. A. 97, 13156-13161.

Pancer, Z., Rast, J.P., Davidson, E.H., 1999. Origins of immunity: transcription factors and homologues of effector genes of the vertebrate immune system expressed in sea urchin coelomocytes. Immunogenetics 49, 773-786.

Pinsino, A., Thorndyke, M.C., Matranga, V., 2007. Coelomocytes and post-traumatic response in the common sea star Asterias rubens. Cell Stress Chaperones 12, 331-341.

Pipe, R.K., Coles, J.A., Carissan, F.M.M., Ramanathan, K., 1999. Copper induced immunomodulation in the marine mussel, Mytilus edulis. Aquat. Toxicol. 46, 43-54

Radhika, M., Nazar, A.K.A., Munuswamy, N., Nellaiappan, K., 1998. Sex-linked differences in phenol oxidase in the fairy shrimp Streptocephalus dichotomus Baird and their possible role (Crustacea: Anostraca). Hydrobiologia 377, 161-164. 
Rheins, L.A., Karp, R.D., 1985. Effect of gender on the inducible humoral immune response to honeybee venom in the American cockroach (Periplaneta americana). Dev. Comp. Immunol. 9, 41-49.

Rolff, J., 2001. Effects of age and gender on immune function of dragonflies (Odonata, Lestidae) from a wild population. Can. J. Zool. 79, 2176-2180.

Schillaci, D., Arizza, V., Parrinello, N., Di Stefano, V., Fanara, S., Muccilli, V., Cunsolo, V., Haagensen, J.J., Molin, S., 2010. Antimicrobial and antistaphylococcal biofilm activity from the sea urchin Paracentrotus lividus. J. Appl. Microbiol. 108, 17-24.

Schillaci, D., Petruso, S., Sciortino, V., 2005. 3,4,5,3',5'-Pentabromo-2-(2'-hydroxybenzoyl) pyrrole: a potential lead compound as anti-Gram-positive and anti-biofilm agent. Int. J. Antimicrob. Agents 25, 338-340.

Schleder, D.D., Kayser, M., Suhnel, S., Ferreira, J.F., Rupp, G.S., Barracco, M.A., 2008 Evaluation of hemato-immunological parameters during the reproductive cycle of the scallop Nodipecten nodosus in association with a carotenoid-enriched diet. Aquaculture 280, 256-263.

Schmid-Hempel, P., 2003. Variation in immune defence as a question of evolutionary ecology. Proc. Biol. Sci. 270, 357-366.

Shyu, A.B., Raff, R.A., Blumenthal, T., 1986. Expression of the vitellogenin gene in female and male sea urchin. Proc. Natl. Acad. Sci. U. S. A. 83, 3865-3869.

Smith, L.C., Chang, L., Britten, R.J., Davidson, E.H., 1996. Sea urchin genes expressed in activated coelomocytes are identified by expressed sequence tags. Complement homologues and other putative immune response genes suggest immune system homology within the deuterostomes. J. Immunol. 156, 593-602.

Smith, L.C., Ghosh, J., Buckley, K.M., Clow, L.A., Dheilly, N.M., Haug, T., Henson, J.H., Li, C., Lun, C.M., Majeske, A.J., Matranga, V., Nair, S.V., Rast, J.P., Raftos, D.A., Roth, M. Sacchi, S., Schrankel, C.S., Stensvag, K., 2010. Echinoderm immunity. Adv. Exp. Med. Biol. 708, 260-301.

Sodergren, E., Weinstock, G.M., Davidson, E.H., Cameron, R.A., Gibbs, R.A., Angerer, R.C., Angerer, L.M., Arnone, M.I., Burgess, D.R., Burke, R.D., Coffman, J.A., Dean, M., Elphick, M.R., Ettensohn, C.A., Foltz, K.R., Hamdoun, A., Hynes, R.O., Klein, W.H. Marzluff, W., McClay, D.R., Morris, R.L., Mushegian, A., Rast, J.P., Smith, L.C., Thorndyke, M.C., Vacquier, V.D., Wessel, G.M., Wray, G., Zhang, L., Elsik, C.G., Ermolaeva, O., Hlavina, W., Hofmann, G., Kitts, P., Landrum, M.J., Mackey, A.J., Maglott, D., Panopoulou, G., Poustka, A.J., Pruitt, K., Sapojnikov, V., Song, X. Souvorov, A., Solovyev, V., Wei, Z., Whittaker, C.A., Worley, K., Durbin, K.J., Shen, Y., Fedrigo, O., Garfield, D., Haygood, R., Primus, A., Satija, R., Severson, T., GonzalezGaray, M.L., Jackson, A.R., Milosavljevic, A., Tong, M., Killian, C.E., Livingston, B.T., Wilt, F.H., Adams, N., Belle, R., Carbonneau, S., Cheung, R., Cormier, P., Cosson, B., Croce, J., Fernandez-Guerra, A., Geneviere, A.M., Goel, M., Kelkar, H., Morales, J., Mulner-Lorillon, O., Robertson, A.J., Goldstone, J.V., Cole, B., Epel, D., Gold, B., Hahn, M.E., Howard-Ashby, M., Scally, M., Stegeman, J.J., Allgood, E.L., Cool, J., Judkins, K.M. McCafferty, S.S., Musante, A.M., Obar, R.A., Rawson, A.P., Rossetti, B.J., Gibbons, I.R., Hoffman, M.P., Leone, A., Istrail, S., Materna, S.C., Samanta, M.P., Stolc, V., Tongprasit, W., Tu, Q., Bergeron, K.F., Brandhorst, B.P., Whittle, J., Berney, K. Bottjer, D.J., Calestani, C., Peterson, K., Chow, E., Yuan, Q.A., Elhaik, E., Graur, D., Reese, J.T., Bosdet, I., Heesun, S., Marra, M.A., Schein, J., Anderson, M.K., Brockton, V., Buckley, K.M., Cohen, A.H., Fugmann, S.D., Hibino, T., Loza-Coll, M., Majeske, A.J
Messier, C., Nair, S.V., Pancer, Z., Terwilliger, D.P., Agca, C., Arboleda, E., Chen, N., Churcher, A.M., Hallbook, F., Humphrey, G.W., Idris, M.M., Kiyama, T., Liang, S., Mellott, D., Mu, X., Murray, G., Olinski, R.P., Raible, F., Rowe, M., Taylor, J.S., TessmarRaible, K., Wang, D., Wilson, K.H., Yaguchi, S., Gaasterland, T., Galindo, B.E., Gunaratne, H.J., Juliano, C. Kinukawa, M., Moy, G.W., Neill, A.T., Nomura, M., Raisch, M., Reade, A., Roux, M.M., Song, J.L., Su, Y.H., Townley, I.K., Voronina, E., Wong, J.L., Amore, G., Branno, M., Brown, E.R., Cavalieri, V., Duboc, V., Duloquin, L., Flytzanis, C., Gache, C., Lapraz, F., Lepage, T., Locascio, A., Martinez, P., Matassi, G., Matranga, V., Range, R., Rizzo, F., Rottinger, E., Beane, W., Bradham, C., Byrum, C., Glenn, T., Hussain, S., Manning, G., Miranda, E., Thomason, R., Walton, K., Wikramanayke, A., Wu, S.Y., Xu, R., Brown, C.T., Chen, L., Gray, R.F., Lee, P.Y., Nam, J., Oliveri, P., Smith, J., Muzny, D., Bell, S., Chacko, J., Cree, A., Curry, S., Davis, C., Dinh, H., Dugan-Rocha, S., Fowler, J., Gill, R., Hamilton, C., Hernandez, J., Hines, S., Hume, J., Jackson, L., Jolivet, A., Kovar, C., Lee, S., Lewis, L., Miner, G., Morgan, M., Nazareth, L.V., Okwuonu, G., Parker, D., Pu, L.L., Thorn, R., Wright, R., 2006. The genome of the sea urchin Strongylocentrotus purpuratus. Science 314, 941-952.

Stabili, L., Canicatti, C., 1994. Antibacterial activity of the seminal plasma of Paracentrotus lividus. Can. J. Zool. 72, 1211-1216.

Stabili, L., Pagliara, P., Roch, P., 1996. Antibacterial activity in the coelomocytes of the sea urchin Paracentrotus lividus. Comp. Biochem. Physiol. B Biochem. Mol. Biol. 113, 639-644.

Terres, G., Morrison, S.L., Habicht, G.S., 1968. A quantitative difference in the immune response between male and female mice. Proc. Soc. Exp. Biol. Med. 127, 664-667.

Travers, M.A., Le Goic, N., Huchette, S., Koken, M., Paillard, C., 2008. Summer immune depression associated with increased susceptibility of the European abalone, Haliotis tuberculata to Vibrio harveyi infection. Fish Shellfish Immunol. 25, 800-808.

Visconti, G., Agnetta, D., Gianguzza, P., Musmeci, M.T., Piscopo, L., Riggio, S., 2008. Ciclo riproduttivo e gametogenesi di Paracentrotus lividus (Echinodermata Echinoidea) nell'AMP "Isola di Ustica". Acta of XVIII Congresso Nazionale SItE, Parma

Wardlaw, A.C., Unkles, S.E., 1978. Bactericidal activity of celomic fluid from sea-urchin Echinus esculentus. J. Invertebr. Pathol. 32, 10.

Yourth, C.P., Forbes, M.R., Baker, R.L., 2002. Sex differences in melanotic encapsulation responses (immunocompetence) in the damselfly Lestes forcipatus Rambur. Can. J. Zool. 80, 1578-1583.

Yui, M.A., Bayne, C.J., 1983. Echinoderm immunology: bacterial clearance by the sea urchin Strongylocentrotus purpuratus. Biol. Bull. 165, 14.

Zasloff, M., 2002. Antimicrobial peptides in health and disease. N. Engl. J. Med. 347, 1199-1200.

Zhang, Z.H., Li, X.X., Vandepeer, M., Zhao, W., 2006. Effects of water temperature and air exposure on the lysosomal membrane stability of hemocytes in pacific oysters, Crassostrea gigas (Thunberg). Aquaculture 256, 502-509.

Zuk, M., 1990. Reproductive strategies and disease susceptibility: an evolutionary viewpoint. Parasitol. Today 6, 231-233.

Zuk, M., McKean, K.A., 1996. Sex differences in parasite infections: patterns and processes. Int. J. Parasitol. 26, 1009-1023.

Zuk, M., Simmons, L.W., Rotenberry, J.T., Stoehr, A.M., 2004. Sex differences in immunity in two species of field crickets. Can. J. Zool. 82, 627-634. 